\title{
A Case of a 50-Year Old Women with Cerebrospinal Fluid Rhinorrhea and Right Nasal Cavity Mass
}

\author{
Hyoung-Sik Park, Ji-Hun Mo, and Young-Jun Chung \\ Department of Otorhinolaryngology-Head and Neck Surgery, Dankook University College of Medicine, Cheonan, Korea \\ 뇌척수액 비루와 우측 비강 종물을 주소로 내원한 50세 여자 1예 \\ 박형식 · 모지훈 · 정영준 \\ 단국대학교 의과대학 이비인후-두경부외과학교실
}

\author{
Received March 7, 2020 \\ Revised May 5, 2020 \\ Accepted May 18, 2020 \\ Address for correspondence \\ Young-Jun Chung, MD \\ Department of Otorhinolaryngology- \\ Head and Neck Surgery, \\ Dankook University \\ College of Medicine, \\ 201 Manghyang-ro, Dongnam-gu, \\ Cheonan 31116, Korea \\ Tel $+82-41-550-3974$ \\ Fax $+82-41-556-1090$ \\ E-mail entdocjung@daum.net
}

A 50-year-old woman visited the hospital with persistent watery rhinorrhea which she had for 2 months. Endoscopic examination revealed a mass in the right nasal cavity and rdiological findings revealed a bony defect on the lateral wall of the sphenoid sinus associated with the protrusion of the mass lesion. Endoscopic skull base reconstruction was performed via transpterygoid approach, including a watertight closure of the dural defect with both underlay and overlay repairs. Cerebrospinal fluid (CSF) leakage persisted after reconstruction. The right lateral lamella was identified as a secondary CSF leakage site. CSF leakage is common among patients with meningoencephalocele. However, a secondary CSF leakage accompanied with meningoencephalocele in other areas is uncommon. The present patient experienced CSF leakage from multiple sites - one associated with the original meningoencephalocele and another from a secondary defect at the skull base. This complication is rare in clinical practice. Here, we describe this rare case with a brief literature review.

Korean J Otorhinolaryngol-Head Neck Surg 2021;64(3):197-201

Key Words Cerebrospinal fluid leakage · Fluorescein · Intrathecal injection · Encephalocele.

\section{서 론}

뇌류(encephalocele)는 지주막하 연결을 유지한 채로 신경 조직이 중추신경계에서 탈출한 것을 의미한다. 뇌류에 포함된 신경조직에 따라 수막조직만 있으면 수막류, 뇌조직과 수막조 직이 있으면 뇌수막류 등으로 분류한다.,2)

신경조직의 탈출 위치에 따라 후두뇌류, 전두뇌류, 기저뇌 류로 나뉘며 전체 뇌류의 약 $15 \%$ 가 비뇌류(전두뇌류, 기저뇌 류)로 발생한다. ${ }^{3)}$ 기저뇌류는 전두개와에 결손이 있으므로 뇌 류가 비강, 비인강 또는 안와 부위에 발생하고 위치에 따른 증 상들이 나타나며, 경사골형, 접형사골형, 경접형형, 정형안와

This is an Open Access article distributed under the terms of the Creative Commons Attribution Non-Commercial License (https://creativecommons.org/licenses/by-nc/4.0) which permits unrestricted non-commercial use, distribution, and reproduction in any medium, provided the original work is properly cited.
형 등 여러 가지 형태로 발현된다. 크기는 다양하며 이에 따라 나타나는 증상도 달라서 양안과다격리증(hypertelorism), 피 부의 색소침착, 주름, 비후 혹은 얇아지는 소견을 보인다. 뇌 류는 일반적으로 푸르스름한 압축성의 종괴로, 빛에 투과되 는 양상을 보이며, 환아가 울거나, 경정맥 압박 시에 뇌류가 확 장되는 Furstenberg 징후 양성소견을 보이고, 뇌척수액의 누 출이나 박동의 전달이 느껴지기도 한다. ${ }^{4}$ 기저뇌류는 경우에 따라 수년간 발견되지 않는 경우도 있다.5)

뇌척수액 비루는 뇌류의 흔한 증상이지만, 뇌류가 있는 병 변 부위 외에서 동시에 다발성으로 뇌척수액 누출이 있는 경 우는 보고된 바가 없다. 저자들은 최근 뇌류 부위 외에 다른 부위의 뇌기저부 결손에 의한 다발성 뇌척수액 누출이 발생 한 드문 증례를 경험하여 이를 문헌 고찰과 함께 보고하는 바 이다. 


\section{증 례}

50 세 여자가 2개월 전부터 시작된 맑은 콧물을 주소로 내 원하였다. 이전에 특이 과거력이나 외상 이력이 없으며 고개

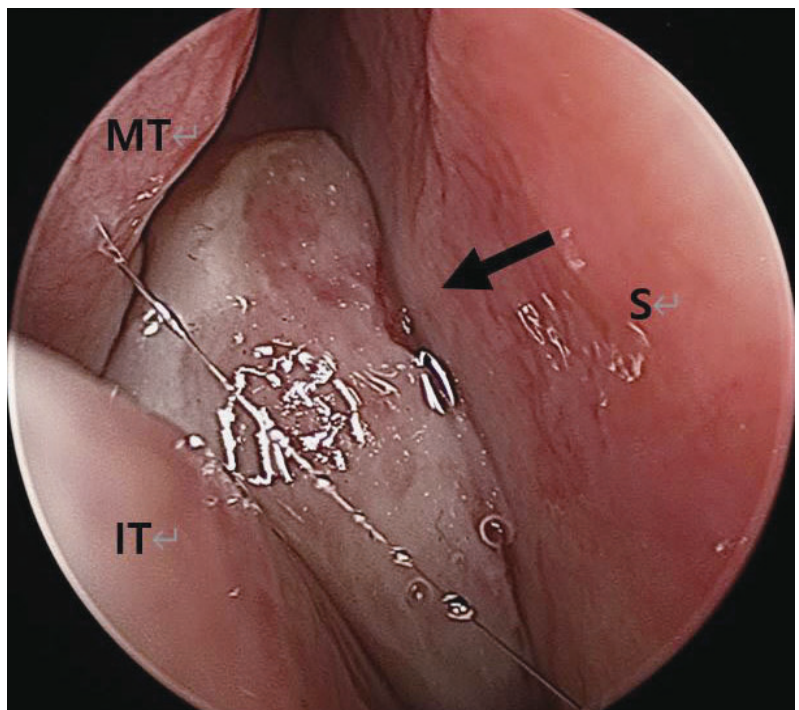

Fig. 1. Preoperative endoscopic findings. Menigoencephalocele (arrow) is observed between the nasal S and MT in the right nasal cavity. S: septum, MT: middle turbinate, IT: inferior turbinate.
를 숙일 시 우측 비강에서 맑은 콧물이 나온다고 하였으며, 코 막힘이나 두통 등 다른 증상들은 호소하지 않았다. 과거력 상 반복적인 뇌수막염 등의 병력은 없었으며, 키 $160 \mathrm{~cm}$, 몸 무게 $70 \mathrm{~kg}$ 로 신체질량지수(body mass index) 27.34로 비만 에 해당하였다. 신경학적 증상은 전혀 없었으며, 양안 과다 격 리나 사시 또한 없었다.

내원 후 시행한 비내시경 검사에서 우측 비강을 채우고 있 는 종물이 관찰되었다(Fig. 1). 부비동 전산화단층촬영술 (CT)상 우측 비강 및 접형동을 채우는 종물을 시사하는 혼 탁 소견과 더불어 우측 접형동의 측벽 부위에 골 결손이 관 찰되었다. 부비동 자기공명영상(MRI)에서도 마찬가지로 우 측 비강 및 접형동을 포함하는 종물이 있었으며 우측 접형동 의 측벽에 골 결손이 관찰되었고, 비강 종물이 뇌의 조직에 서 이어져 탈출한 소견이 보이며 빈 안장 증후군을 의심할 만 한 empty sella 소견은 없었다(Fig. 2). 비내시경 소견과 영상 학적 소견에 종합하여 임상적으로 경접형형의 기저뇌류로 진 단되었다. 수술 전 신경과에 협진하여 요추천자를 시행하여 두개내압항진 여부를 확인하였으며, 뇌압은 $15 \mathrm{~mm} \mathrm{Hg}$ 로 두 개내압항진은 없었다.

기저뇌류 및 뇌척수액 누출 의심 하에 내비게이션 유도 하
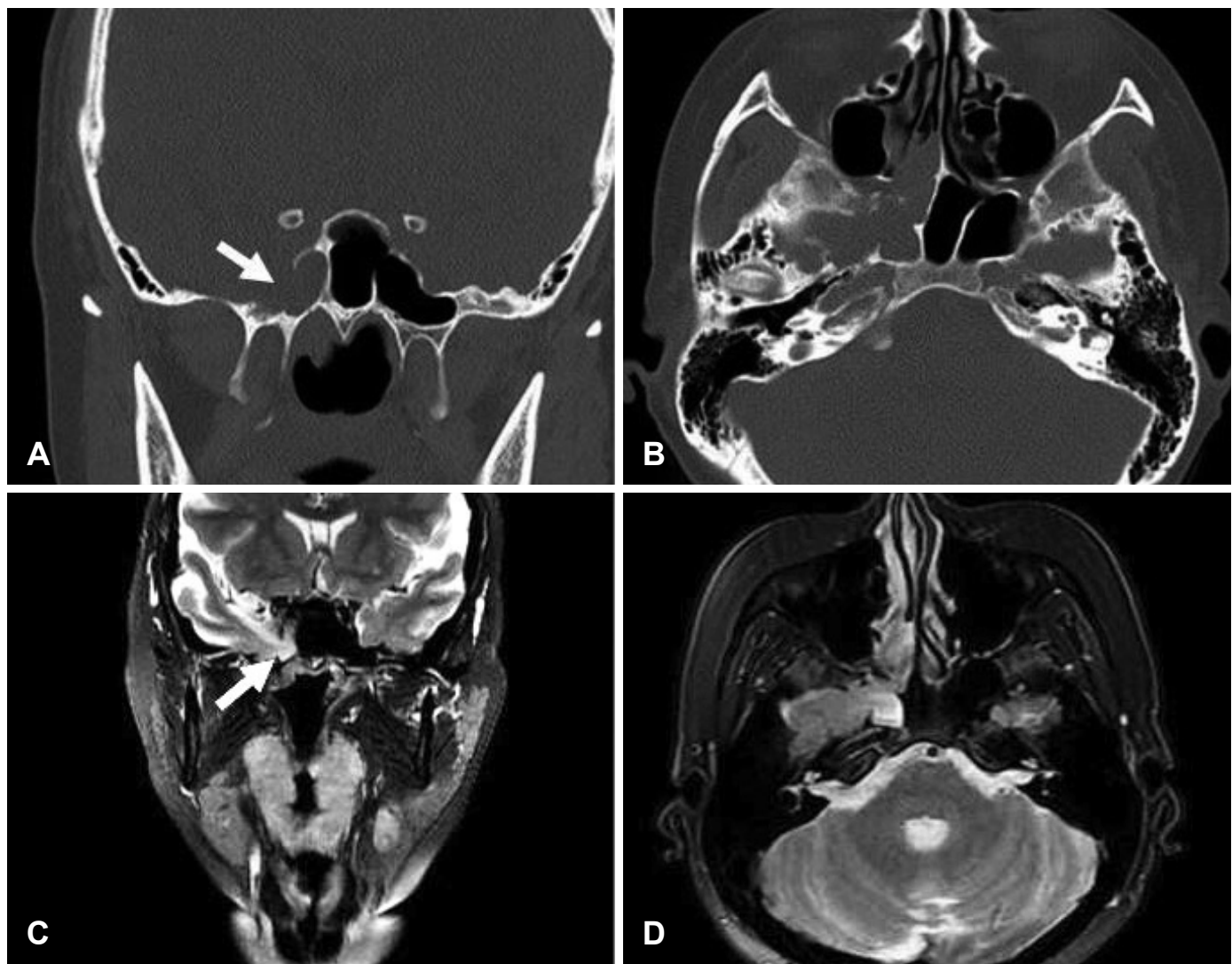

Fig. 2. Preoperative CT and MRI findings of the paranasal sinuses. The coronal and axial CT scans show soft density lesion (arrow) in right sphenoid sinus and defect of lateral wall of right sphenoid sinus (A, B). The coronal and axial T2-weighted MRI scans show a $3.6 \mathrm{~cm}$ extent soft tissue density lesion (arrow) at right sphenoid sinus and herniation of the brain parenchyme through a bone defect $(C, D)$. 
내시경적 두개저 재건술을 진행하였다. 수술 전 뇌척수액 누출 을 면밀히 관찰하기 위해 척수강 내 fluorescein 주사 $(10 \%$ $0.1 \mathrm{~mL}(10 \mathrm{mg})$ fluorescein dye를 뇌척수액 $10 \mathrm{~mL}$ 와 섞어 서)를 시행하였으며, 우측 넓적다리에서 대퇴근막을 준비하였 다. Transpterygoid 접근을 통해 내시경하 우측 기저뇌류 제 거 및 접형동 결손에 대해 재건술을 시행하였고, 기저뇌류는 전기소작기를 이용하여 제거하였고, 제거 후엔 우측 접형동 측벽에서 $10 \mathrm{~mm}$ 정도의 골 결손부가 발견되었다. 기저뇌류 를 제거한 후 우측 접형동 결손 부위에서 뇌척수액 누출이 발 견되었다. 재건술은 underlay법으로 경막과 두개저골 사이에 대퇴근막, 비중격 골을 끼워 넣었으며, 그 위로 Surgicel ${ }^{\circledR}\left(\mathrm{Eth}^{-}\right.$ icon, Somerville, NJ, USA), Tachocomb ${ }^{\circledR}$ (Nycomed, Zurich, Switzerland), Tisseel ${ }^{\circledR}$ (Baxter Healthcare, Deerfield, IL, USA)를 이용해 고정하였다. 그 위에 추가적으로 overlay법 으로 대퇴근막으로 한 번 더 고정해주었고, 비중격 피판술을
이용하여 최종적으로 결손 부위를 재건하였다. 우측 접형동 결손 부위 재건술 시행 이후에도 지속적인 뇌척수액 누출 소 견이 수술 시야에서 지속적으로 관찰되어 면밀히 비강 및 뇌 기저부를 탐색한 결과, 우측 측판(lateral lamella)에서 다량 의 뇌척수액 누출을 발견하였다(Fig. 3). 이 부위에 대해 비중 격 골조각을 underlay법으로 끼워 넣었으며, 그 위로 대퇴근 막을 덮은 후 Tachocomb ${ }^{\circledR}$, Tisseel ${ }^{\circledR}$ 를 이용하여 고정하여 추가적인 재건술을 시행하였다. 이후 수술 시야에서 더 이상 의 뇌척수액 누출이 없음을 확인한 후 수술을 종료하였다.

수술 후 뇌척수압을 측정하였고, $18 \mathrm{~mm} \mathrm{Hg}$ 로 정상 두개 내압 수치 내로 유지되었으며 뇌척수액 누출의 가능성을 줄 이기 위해 1 주 간 요추 배액관을 유지하고, 침상 안정 및 항히 스타민제, 진해제, 완하제(laxative) 등을 사용하는 보존적인 요법을 계획하였다. 수술 후 3일까지 소량의 비분비물에서 double-ring sign이 관찰되어 뇌척수액누출이 의심되었지만,
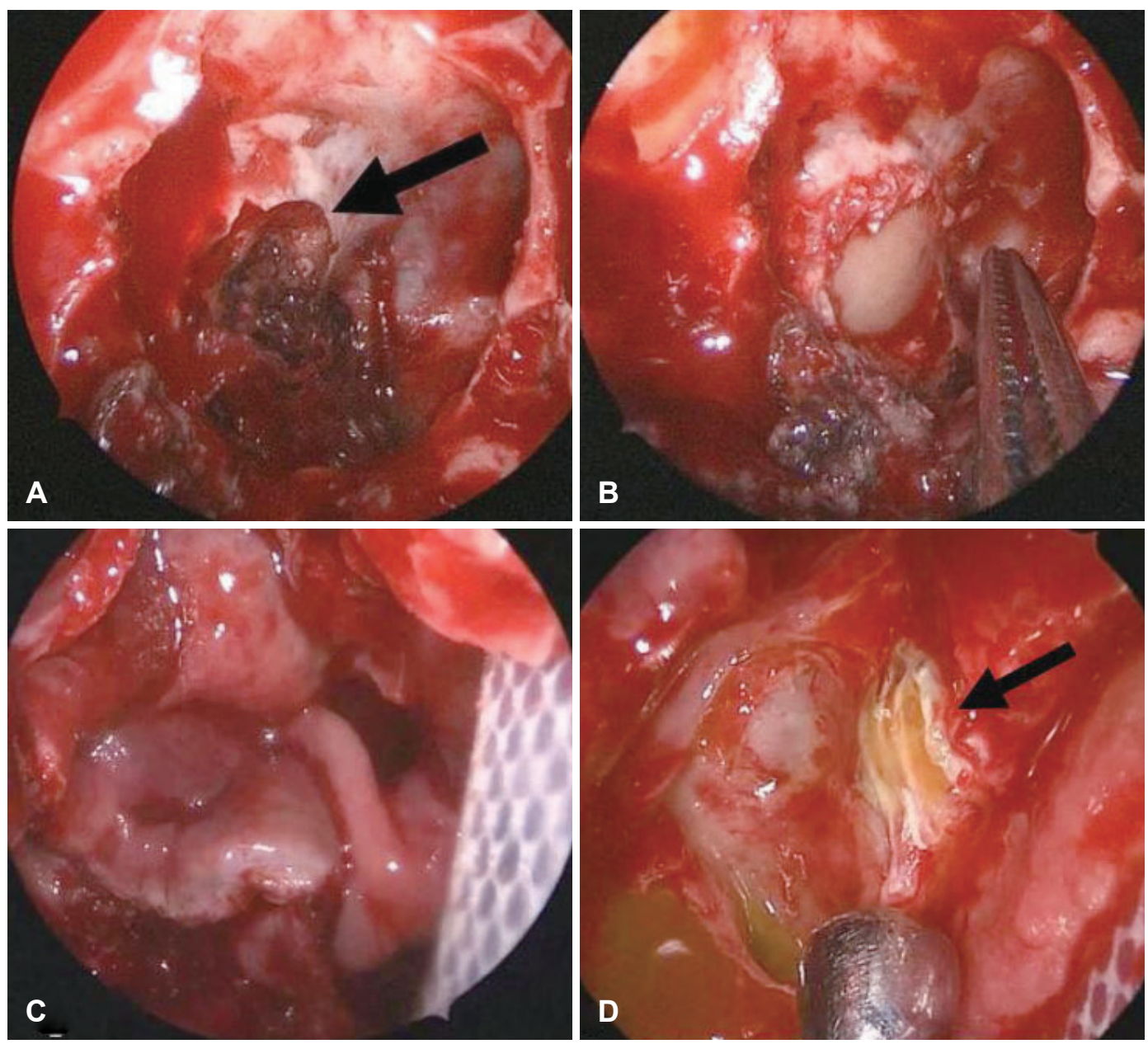

Fig. 3. Endoscopic findings during surgery. About $10 \mathrm{~mm}$ of defect (arrow) is found at lateral wall of right sphenoid sinus after removal of the mass (A). Using underlay, fascia lata and septal bone are inserted between dura and skull base (B). Using Surgicel ${ }^{\circledR}$ (Ethicon, Somerville, NJ, USA), Tachocomb ${ }^{\circledR}$ (Nycomed, Zurich, Switzerland), and Tisseel ${ }^{\circledR}$ (Baxter Healthcare, Deerfield, IL, USA), under lay is fixed. Using overlay, fascia lata and nasoseptal flap is covered and reconstruction is finished (C). After reconstruction of lateral wall of right sphenoid wall, continuous CSF leakage is found, a large amount of CSF leakage is identified at right lateral lamella (arrow) (D). CSF: cerebrospinal fluid. 
pseudo-halo sign 가능성이 높아 경과를 관찰하였고 그 이 후에는 관찰되지 않았다. 수술 후 3일째 두통 및 구역, 구토 증상 있어 뇌척수액 검사를 시행하였으며 감염 소견이 있어 경험적 항생제(vancomycin, ceftazidime)을 사용하였다. 수 술 후 5일째 두통, 요통, 구역, 구토 증상 지속되고, 요추 배액 관의 기능 장애가 의심이 되어 제거하였다.

이후 특이 증상은 없었으며 수술 시 충전해 놓았던 Mero$\mathrm{cel}^{\circledR}$ (Medtronic Inc., Minneapolis, MN, USA)을 교환할 목 적으로 술후 10 일째 제거 후 재건 부위를 관찰한 결과 피판 의 색은 양호하였고 뇌척수액 누출 소견도 관찰되지 않았다 (Fig. 4). Merocel ${ }^{\circledR}$ 을 교환하여 충전한 후 다음날 퇴원하였다. Merocel ${ }^{\circledR}$ 은 10 일째 더 유지한 후 제거하였다. 환자는 술후 32일까지 뇌척수액 누출 및 뇌류 소견 없이 외래에서 경과 관 찰하였고, 이후에는 본국인 우즈벡키스탄으로 돌아가 추적 관찰은 하지 못하였다. 추후 한국을 다시 방문하는 경우에 병 원을 재방문할 것을 권고하였다.

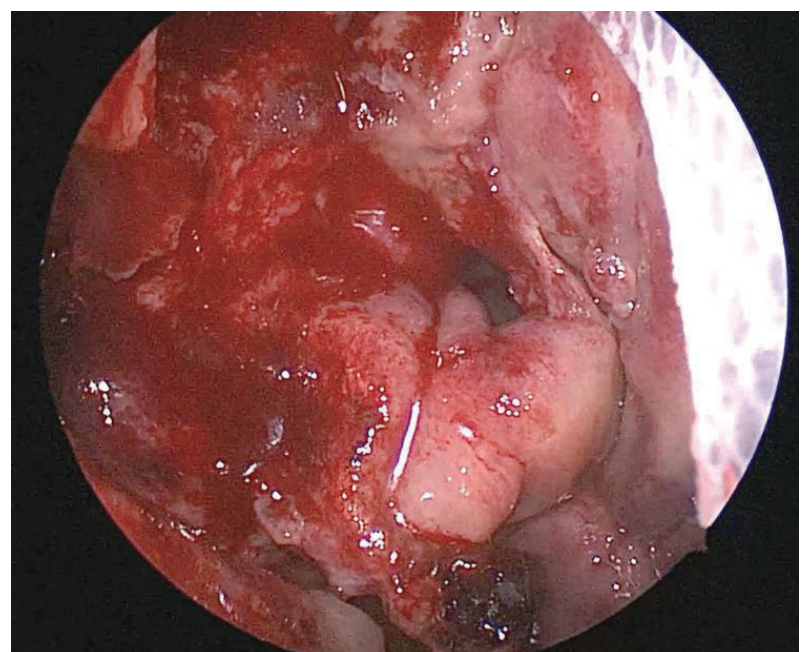

Fig. 4. Endoscopic findings at 10 days after the operation.

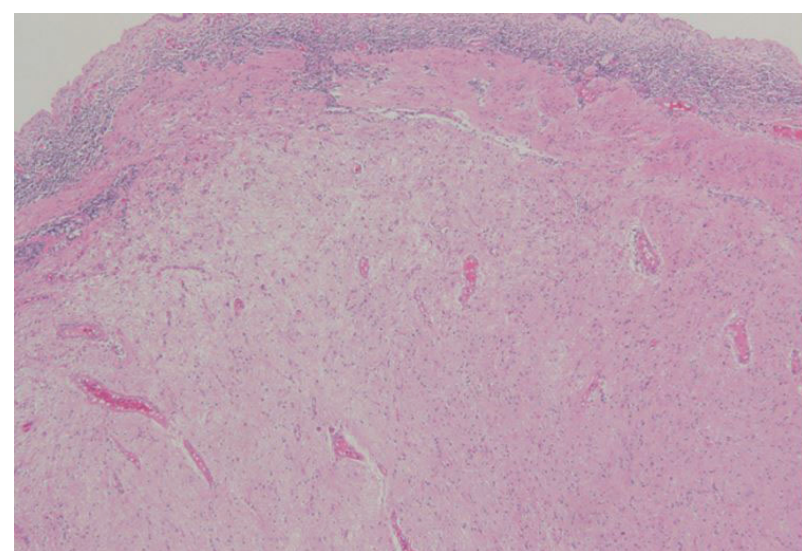

Fig. 5. Histologic findings show meningoencephalocele. Brain tissue and glial cells are noted (H\&E, ×100). H\&E: hematoxylin and eosin.
절제된 검체의 병리학적 결과 뇌막을 포함한 신경세포와 교세포들이 확인되어 뇌수막류로 진단되었다(Fig. 5).

\section{고 찰}

성인의 자연적 뇌척수액 비루는 선천성 혹은 후천성일 수 있다. 후천성의 원인은 잘 알려져 있지는 않지만, 노화와 부비 동의 함기화로 인한 두개저의 벌어짐으로 생각되고 있다. 과 체중이나 비만 또한 두개 내 압력을 증가시키고 자연적인 뇌 척수액 비루를 증가시키는 요인으로 보고 있다.6,7)

기저뇌류는 전두개와에 결손이 있으므로 뇌류가 비강, 비 인강 또는 안와 부위에 발생하고 위치에 따른 증상들이 나타 나며, 경사골형, 접형사골형, 경접형형, 접형안와형 등 여러 형 태로 발현된다. 경접형형 뇌류는 기저뇌류의 $5 \%$ 를 차지한다. 본 사례에서는 기저뇌류에서도 발생률이 낮은 경접형형에 속 한다. ${ }^{8}$

다발성 뇌척수액 누출은 골 용해를 일으킬 수 있는 전신 질 환인 Gorham-Stout syndrome이나 connective tissue disease에서 있을 수 있는데 본 사례의 환자는 전신적 증상이 없 었으며 다른 기저질환은 없었다.

수술 전 두개저 결손 부위를 확인하기 위해 CT와 MRI를 촬영할 수 있으며 보조적으로 뇌수조조영술(cisternography) 을 이용할 수 있다. 본 사례에서 CT와 MRI를 촬영했으며 수 술 전 결손부위를 미리 예측할 수 있었다. 하지만 본 사례에 서는 결손 부위(우측 접형동의 측벽)를 재건하였는데도 뇌척 수액의 누출이 지속적으로 관찰되어 뇌척수액 누출이 뇌류가 있는 부위 외에서 추가적으로 발견되었다. 이 같은 누출은 수 술 전 CT와 MRI에서는 우측 측판의 결손이 뚜렷하게 보이 지 않아(Fig. 6), 수술 전 척수강 내 fluorescin 주입술을 하지 않았다면 발견하지 못했을 것으로 판단되어 술전 척수강 내 fluorescin 주입술의 필요성을 확인할 수 있었다.

수술 후에 right lateral lamella 부위에 대하여 후향적으 로 CT를 확인하였으며 lateral lamella 부위나 다른 뇌기저 부위에서 발견된 뚜렷한 골견손이나 골미란 소견은 없었다.

척수강 내 fluorescin 주입술은 여러 가지 부작용이 보고 되고 있다. 눈물색과 소변색의 변화, 두통, 목 통증, 오심, 구 토, 열, 뇌 신경 결손, 하지 위약감, 저린감들은 흔히 보고되는 부작용이다. 드물지만 더 심각한 부작용인 뇌전증 발작, 활모 양강직, 편측마비, 언어장애, 골수병증, 폐부종, 그리고 사망까 지 이를 수 있다. ${ }^{9-12)}$ 하지만 최근 논문에 따르면 저용량으로 사용할 경우 안전하고 합병증 없이 fluorescein을 사용할 수 있다고 보고되고 있다. ${ }^{13,14)}$ 또한 본 증례처럼 두개저 수술에 있어서 예측하지 못한 뇌척수액 누출의 정확한 위치를 파악 

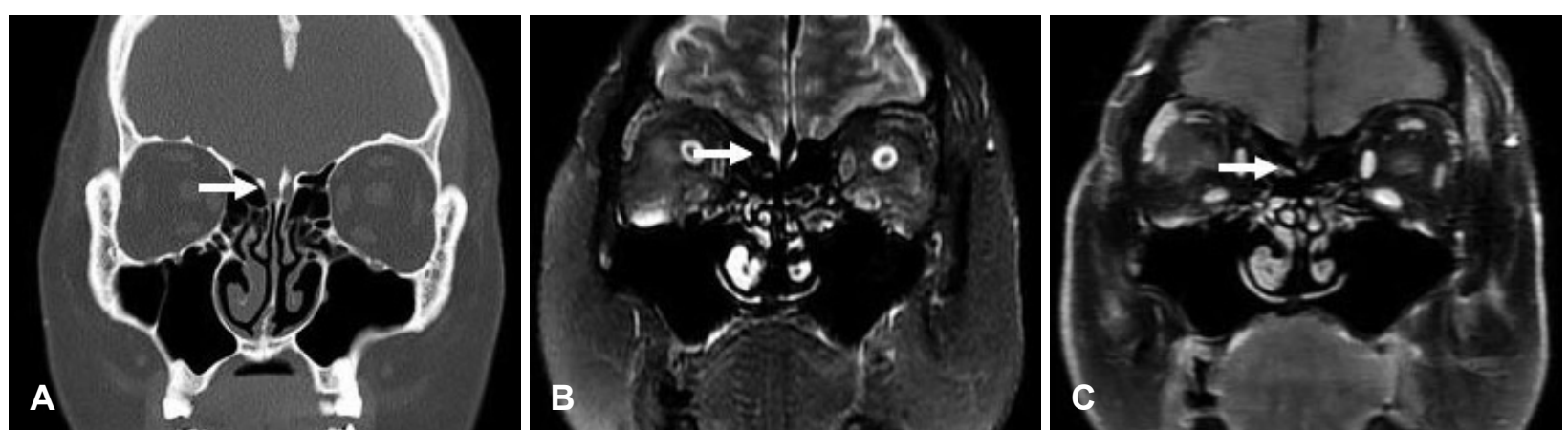

Fig. 6. Preoperative CT and MRI findings of the paranasal sinuses. The coronal CT (A), MRI T2, and T1 enhancing (B, C) scans show no defect at right lateral lamella (arrow).

하는데 도움이 될 수 있으므로 저용량으로 fluorescein을 사 용하는 것이 바람직할 것으로 생각 된다.

Halo sign은 거즈에 형성된 고리 모양으로 혈액과 뇌척수액 이 분리되었음을 나타내며 뇌척수액 누출을 의심할 수 있는 징후이다. 그러나 이 징후는 뇌척수액에만 한정되지 않으며 침, 눈물, 그리고 코 분비물에서도 보일 수 있어 특이도가 낮 다. ${ }^{15)}$ 그러므로 두개저 수술 후 halo sign이 보인다고 하여 바 로 뇌척수액 누출을 의심하는 것보단 위양성일 가능성이 있 음을 인지하는 것이 중요하다.

본 사례에서 환자의 비강 내 종물인 뇌류는 선천적으로 있 었다고 생각되며, 3 개월 전부터 발생한 맑은 콧물, 즉 증상의 원인은 비만 등으로 인한 뇌압상승으로 우측 측판의 결손이 새로 생기면서 발생된 것이라 저자는 생각하고 있다. 수술 전 촬영한 $\mathrm{CT}, \mathrm{MRI}$ 에서 두개저의 결손 및 기저뇌류를 확인한다 하더라도 수술 부위 이외에서 발생되는 뇌척수액 누출에 대해 서는 예측하기는 쉽지 않을 것이다.

본 사례는 뇌척수액 누출이 뇌류가 있는 병변 외에 추가적 으로 다른 뇌기저부 결손에 의해 다발성 뇌척수액 누출이 발 생한 드문 증례이다. 이에 본 저자는 두개저 수술 시 척수강 내 fluorescin 주입술을 시행하여 이중으로 뇌척수액 누출을 확인하며 수술 시 발생할 수 있는 변수 등과 같은 여러 상황 들에 대해 대비하는 것이 바람직할 것으로 생각된다.

\section{Acknowledgments}

This research was supported by Basic Science Research Program through the National Research Foundation of Korea (NRF) funded by the Ministry of Science, ICT \& Future Planning (2019R1 F1A1060589).

\section{Author Contribution}

Conceptualization: Young-Jun Chung. Data curation: Hyoung-Sik Park. Formal analysis: all authors. Funding acquisition: all authors. Investigation: all authors. Methodology: all authors. Project administration: Young-Jun Chung. Resources: Ji-Hun Mo. Software: all authors. Supervision: Young-Jun Chung. Validation: Young-Jun Chung. Visualization: Young-Jun Chung, Ji-Hun Mo. Writing — original draft: Hyoung-Sik Park. Writing — review \& editing: all authors.

\section{ORCID}

Young-Jun Chung https://orcid.org/0000-0002-3789-3485

\section{REFERENCES}

1) Lotfinia I. Mahdkhah A. Intradiploic meningoencephalocele, case report and review of literature. J Clin Exp Neurosci 2013;1:10.

2) McPheeters MJ, Kainth DS, Lam CH. Spontaneous frontal intradiploic meningoencephalocele. Surg Neurol Int 2015;6(Suppl 27):S651-4.

3) Arai A, Mizukawa K, Nishihara M, Fujita A, Hosoda K, Kohmura E. Spontaneous cerebrospinal fluid rhinorrhea associated with a far lateral temporal encephalocele--case report. Neurol Med Chir (Tokyo) 2010;50(3):243-5.

4) Keshri AK, Shah SR, Patadia SD, Sahu RN, Behari S. Transnasal endoscopic repair of pediatric meningoencephalocele. J Pediatr Neurosci 2016;11(1):42-5.

5) Harada N, Nemoto M, Miyazaki C, Kondo K, Masuda H, Nomoto J, et al. Basal encephalocele in an adult patient presenting with minor anomalies: A case report. J Med Case Rep 2014;8:24.

6) Ziade G, Hamdan AL, Homsi MT, Kazan I, Hadi U. Spontaneous transethmoidal meningoceles in adults: Case series with emphasis on surgical management. ScientificWorldJournal 2016;2016:3238297.

7) Das S, Collins T. True transsphenoidal meningoencephalocele. Headache 2017;57(7):1154-5.

8) Suwanwela C, Suwanwela N. A morphological classification of sincipital encephalomeningoceles. J Neurosurg 1972;36(2):201-11.

9) Anari S, Waldron M, Carrie S. Delayed absence seizure: A complication of intrathecal fluorescein injection. A case report and literature review. Auris Nasus Larynx 2007;34(4):515-8.

10) Jacob AK, Dilger JA, Hebl JR. Status epilepticus and intrathecal fluorescein: Anesthesia providers beware. Anesth Analg 2008; 107(1):229-31.

11) Keerl R, Weber RK, Draf W, Radziwill R, Wienke A. Complications of lumbar administration of $5 \%$ sodium fluorescein solution for detection of cerebrospinal fluid fistula. Laryngorhinootologie 2003; 82(12):833-8.

12) Kerr JT, Chu FW, Bayles SW. Cerebrospinal fluid rhinorrhea: Diagnosis and management. Otolaryngol Clin North Am 2005;38(4): 597-611.

13) Camlar M, Turk C, Oltulu F, Oren M, Buhur A, Yigitturk G, et al. How safe is the use of intrathecal fluorescein? An Experimental Study. Turk Neurosurg 2019;29(4):549-54.

14) Javadi SA, Samimi H, Naderi F, Shirani M. The use of low- dose intrathecal fluorescein in endoscopic repair of cerebrospinal fluid rhinorrhea. Arch Iran Med 2013;16(5):264-6.

15) Ray AM. Halo sign is neither sensitive nor specific for cerebrospinal fluid leak. Ann Emerg Med 2009;53(2):288. 